(2) norden 



\section{Prolonged copper release rate study with three pleasure boat antifouling paints}

TemaNord 2008:519 


\section{Prolonged copper release rate study with three pleasure boat antifouling paints}

TemaNord 2008:519

(C) Nordic Council of Ministers, Copenhagen 2007

ISBN 978-92-893-1664-4

Print: Ekspressen Tryk \& Kopicenter

Printed on environmentally friendly paper

This publication can be ordered on www.norden.org/order. Other Nordic publications are available at www.norden.org/publications

Printed in Denmark

\section{Nordic Council of Ministers}

Store Strandstræde 18

DK-1255 Copenhagen K

Phone (+45) 33960200

Fax (+45) 33960202

www.norden.org

\section{Nordic Council}

Store Strandstræde 18

DK-1255 Copenhagen K

Phone (+45) 33960400

Fax (+45) 33111870

\section{Nordic co-operation}

Nordic cooperation is one of the world's most extensive forms of regional collaboration, involving Denmark, Finland, Iceland, Norway, Sweden, and three autonomous areas: the Faroe Islands, Greenland, and Åland.

Nordic cooperation has firm traditions in politics, the economy, and culture. It plays an important rol in European and international collaboration, and aims at creating a strong Nordic community in a strong Europe.

Nordic cooperation seeks to safeguard Nordic and regional interests and principles in the global community. Common Nordic values help the region solidify its position as one of the world's most innovative and competitive. 


\section{Content}

Preface

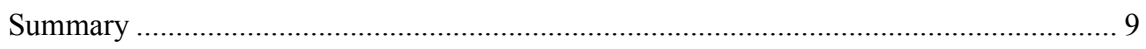

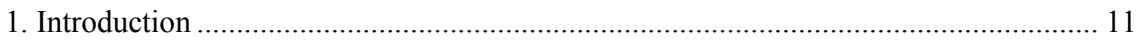

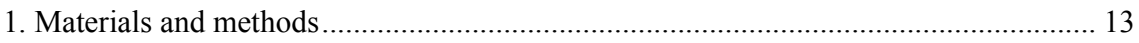

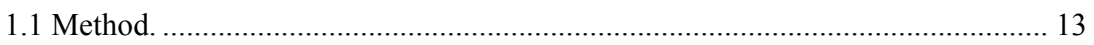

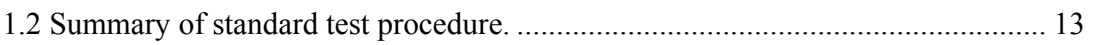

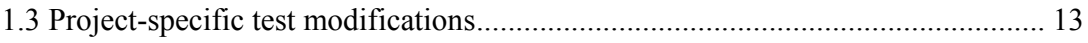

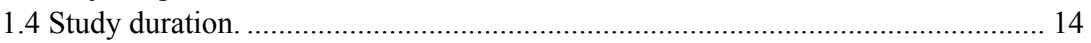

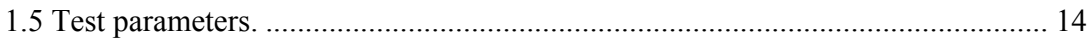

1.6 Studied paints.

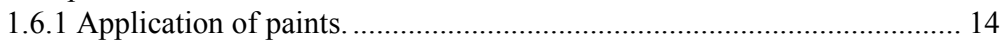

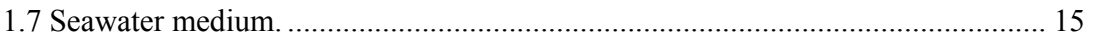

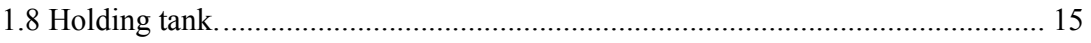

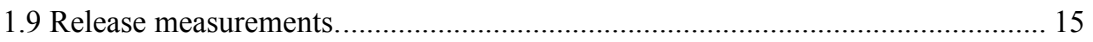

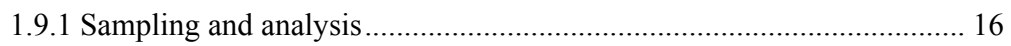

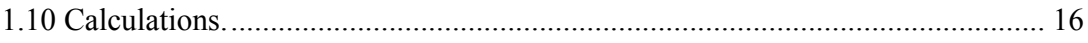

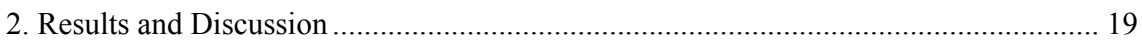

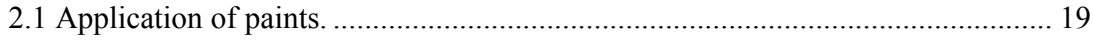

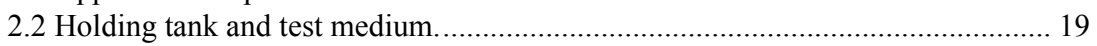

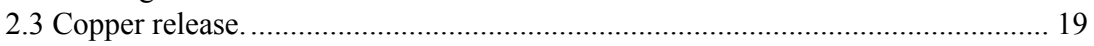

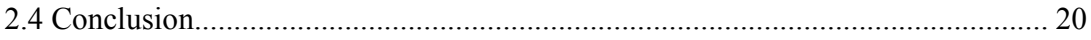

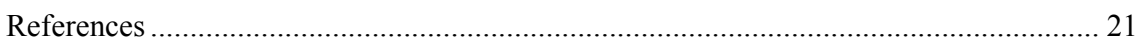

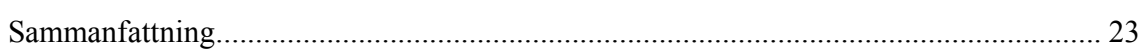

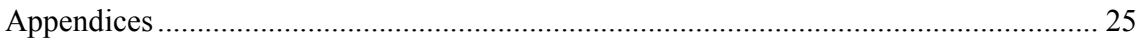

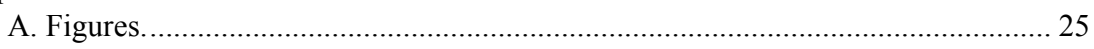

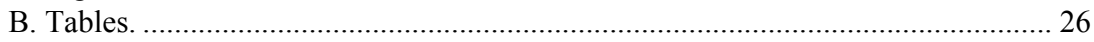

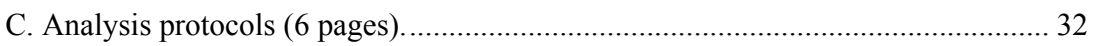

D. Photographs of test cylinders (before and after testing) ........................................ 38 



\section{Preface}

This is a report of a joint Nordic project aimed to evaluate whether a prolongation of a standard method for release tests of active substance, primarily copper, from antifouling products may give information which is of importance for the evaluation of the environmental effects of modern antifouling paints.

The project was carried out by a project group consisting of Kurt Haglund (project leader), Helena Casabona and Markus Johansson, Swedish Chemicals Agency, and supervised by the Nordic Biocides Group, which presently has the following members: Mary Iakovidou and Johan Helgesson, Swedish Chemicals Agency, Sanna Koivisto, Finnish Environment Institute, Anneli Kojo, Finnish National Product Control Agency for Welfare and Health, Jörgen Larsen and Annika Boye Petersen, Danish Environmental Protection Agency, Elin Gudmundsdottir, The Environment and Food Agency of Iceland, Astrid Gaustad, Susanne Hardt and Christian Dons, Norwegian Pollution control Authority.

The project was financially supported by the Nordic Chemicals Group under the Nordic Council of Ministers. The report was written by Åke Forsberg, AB Thalassa (test laboratory) and Kurt Haglund, Swedish Chemicals Agency. 



\section{Summary}

The purpose of the study was to evaluate whether a prolongation of a standard method for release tests of active substance, primarily copper, from antifouling products is possible. The aim is to obtain more information about the release behaviour of the products, which may be of importance for the evaluation of the environmental effects of modern antifouling paints. Long-term copper release rate (122 days) has been measured from three different copper-containing pleasure boat anti-fouling paints available on the Swedish market. It is concluded that a prolonged test may give additional information as compared to a standard 45 days test, primarily regarding how the steady-state release of a paint is reached. 



\section{Introduction}

The purpose of this project was to evaluate whether it is possible to extend a standard method for release (leaching) tests of active substance, primarily copper, from antifouling products in order to obtain information that improves the basis for evaluation of the environmental effects of modern antifouling paints. There is reason to assume that some new antifouling paints for pleasure boats have non-traditional release behaviour in that the copper release rate is low at start (e.g. the first 30 days) and then increases to a higher level. To date, the standard methods normally have a duration of 45 days and thus do not detect this kind of release pattern. Consequently, risks for the aquatic environment due to high release rates later in the service life of the paints will not be detected in the evaluation of antifouling products.

In the present project the default test duration of 45 days has been prolonged to 122 days. Two "modern" antifouling paints have been included in the project, as well as one "traditional" paint. During the planning of the project it was discussed whether additional parameters need to be checked to assure that the conditions of the test are maintained at an acceptable level throughout the test. However, after consultation with a person with good insight into standardisation of this type of test methods (Mr Alistair Finney, presently member of both the ISO and the ASTM standardisation groups) it was decided not to perform any additional measurements.

Depending on the outcome of the project, new suggestions may be made regarding what release test data should be required in the evaluation of antifouling products under the Biocidal Products Directive (98/8/EC). 



\section{Materials and methods}

\subsection{Method.}

The method used in the study is published by the American Society for Testing and Materials, ASTM D 6442-05, "Standard Test Method for Determination of Copper Release Rate from Antifouling Coatings in Substitute Ocean Water" (ASTM 2005). Some minor modifications of the method versus the ASTM standard are listed in Table 1.

Table 1 Parameters and modifications used by Thalassa versus ASTM D 6442-05.

\begin{tabular}{lrr}
\hline & ASTM D 6442-05 & Thalassa \\
\hline test material & Polycarbonate & Polycarbonate \\
temperature $\left({ }^{\circ} \mathrm{C}\right)$ & $25 \pm 1$ & $24.5 \pm 1$ \\
rotation time $(\mathrm{min})$ & 60 & 60 \\
painted area $\left(\mathrm{cm}^{2}\right)$ & 200 & 180 \\
cylinder diameter $(\mathrm{cm})$ & 6.4 & 6.2 \\
rotation speed $\left(\mathrm{min}^{-1}\right)$ & 60 & 60 \\
peripheral speed $\left(\mathrm{m} \mathrm{h}^{-1}\right)$ & 720 & 720 \\
beaker medium vol. $(\mathrm{mL})$ & 1500 & 1500 \\
cylinder surface/medium volume & 0.133 & 0.120 \\
\hline
\end{tabular}

\subsection{Summary of standard test procedure.}

Painted and control cylinders are fixed in a holding tank filled with artificial seawater so that the painted surfaces are completely submerged. At the time of measurement, at intervals stated below, the cylinders are transferred from the holding tank to individual measuring beakers filled with new artificial seawater. Release rates are determined by rotating the cylinders in the beakers for 60 minutes. After the rotation is finished, the cylinders are transferred back to the holding tank and the copper concentrations in the beakers are measured. The copper concentrations are used to calculate the release rates of the paints.

\subsection{Project-specific test modifications}

In this study an additional release measurement was performed at start (day 0 ). The main modification was that the test duration was extended from the standard 45 days to 122 days. 


\subsection{Study duration.}

The experimental part of the study was performed with start 1 August and end 1 December 2006.

\subsection{Test parameters.}

All test material during measurements and the holding tank were held in a thermostated room at the desired temperature, $24.5 \pm 1{ }^{\circ} \mathrm{C}$.

\subsection{Studied paints.}

The following three paints were chosen for the project.

- Paint 1: Fabi (International Paint), reg no: 3959.

- Paint 2: Mille Xtra (Hempel A/S), reg no: 4595.

- Paint 3: Hard Racing Xtra (Hempel A/S), reg no: 4596.

Paints 2 and 3 were chosen to represent modern paints that do not have the same initial "surge" of copper release that often is found in older types of paints, but rather display a more flattened-out release rate curve over time. Release rate data on these paints submitted in 2003 (Hempel 2002a, b) to the Swedish Chemicals Agency (KemI) indicate that the release rate has not reached steady state after 45 days and may increase with time after 45 days. Paint 1 represents a traditional older type of paint with high initial release rate of copper. The paints were purchased from an ordinary shop for boat equipment in the town Västerås, Sweden. The reg. no refers to the Pesticides Register of the Swedish Chemicals Agency.

\subsubsection{Application of paints.}

A total of three paints were applied with brush on cylinders following instructions given by the respective manufacturer with the aim of producing a dry film thickness of minimum $100 \mu \mathrm{m}$. Triplicate cylinders were painted with each paint. The painted cylinders were left to dry for 7 days before start of the test. One cylinder was left unpainted to serve as blank control. 


\subsection{Seawater medium.}

Synthetic seawater prepared according to ASTM D-1411-90 (ASTM 1998), excluding addition of trace metals (Solution 3), was used throughout the test. When following this recipe, the resulting salinity of the water was 35-36 ppt, which was further diluted to a salinity between 33 and 34 ppt. Before each release measurement, new seawater was prepared in two $25 \mathrm{~L}$ communicating plastic containers and recirculated over an ion exchange column (Amberlite IRC 718) to reduce cation (primarily $\mathrm{Cu}^{++}$) content. This seawater was prepared just after finishing one measurement and then used at the following measurement. Salinity, $\mathrm{pH}$ and copper content were measured regularly.

\subsection{Holding tank.}

As holding tank served two $120 \mathrm{~L} \mathrm{PE}$ (polyethylene) aquaria connected in series with $100 \mathrm{~L}$ of synthetic seawater in each tank. In Table 2 (Appendix A) they are referred to as Holding Tank I and Holding Tank II. The seawater was continuously recirculated using an aquarium pump (Eheim) at a rate of ca $350 \mathrm{~L} \mathrm{~h}^{-1}$ through nozzles that created a flow past the cylinders in the tank. Another similar pump recirculated the water, at a rate of ca $30 \mathrm{~L} \mathrm{~h}^{-1}$, through an Amberlite IRC 718 ion exchange column which continuously removed $\mathrm{Cu}^{++}$from the seawater.

The water in holding tank system was inspected regularly and monitored for $\mathrm{pH}$, conductivity and temperature, see Table 3 . The tanks were open so that the water surface was in contact with the air in the $4 \mathrm{~m}^{2}$ testing room, which was temperature controlled. Over time some material from the test cylinders accumulated on the bottom of the tanks. Due to the circulation pattern in the tanks the debris is concentrated in spots on the bottom. With a special aspirator (a glass tube connected to a vacuum pump) the material was removed once per week from the system.

\subsection{Release measurements.}

Measurements of release rates were done at $0,1,3,5,8,11,14,18,22$, $26,30,36,40,45,52,59,66,73,80,87,94,101,108,115$ and 122 days after start of the test. The release measurement procedure followed ASTM D 6442-05 (paragraph 9.8) with the modifications indicated in Table 1. The $\mathrm{pH}$ of the seawater medium used for measurement was kept at $8.0 \pm 0.1$. Care was taken to avoid drying of the painted surfaces whilst transferring them between the holding tank and the measuring beakers. 


\subsubsection{Sampling and analysis}

Immediately after completion of the cylinder rotation and subsequent removal of the cylinders from the measuring beakers, samples of $20 \mathrm{~mL}$, in duplicates, from each beaker were transferred to acid-washed and numbered PE scintillation vials using acid-washed pipette tips. The samples were stored in a freezer $\left(-18^{\circ} \mathrm{C}\right)$ until analysed. The samples were analyzed by a laboratory close to our facility (MeAna consult). Analyses of copper content in one of the samples from each beaker were done as single analysis using flame atomic absorption spectrophotometry (AAS) equipped with graphite furnace. The detection limit, defined as three times the variation between the blanks, has been slightly different at different analysis occasions, and varies between 2 and $5 \mu \mathrm{g} \mathrm{L} \mathrm{L}^{-1}$.

\subsection{Calculations.}

The release rate (R) is expressed as $\mu \mathrm{g} \mathrm{Cu} \mathrm{cm}^{-2} \mathrm{~d}^{-1}$ and calculated as follows:

$$
\mathrm{R}=\left(\left(\mathrm{C}_{\mathrm{S}}-\mathrm{C}_{\mathrm{B}}\right) * \mathrm{~V} * \mathrm{D}\right) /(\mathrm{T} * \mathrm{~A})
$$

where:

$$
\begin{aligned}
& \mathrm{C}_{\mathrm{S}}=\text { copper concentration in sample }\left(\mu \mathrm{g} \mathrm{L}^{-1}\right) \\
& \mathrm{C}_{\mathrm{B}}=\text { copper concentration in blank }\left(\mu \mathrm{g} \mathrm{L}^{-1}\right) \\
& \mathrm{D}=\text { hours/day } \\
& \mathrm{V}=\text { volume of seawater in measuring container }(\mathrm{L}, \text { litres) } \\
& \mathrm{T}=\text { time of cylinder immersion in measuring container (h, hours) } \\
& \mathrm{A}=\text { surface area of paint film }\left(\mathrm{cm}^{2}\right)
\end{aligned}
$$

in this study:

$$
\begin{aligned}
& D=24 \mathrm{~h} \\
& V=1.5 \mathrm{~L} \\
& T=1 \mathrm{~h} \\
& A=180 \mathrm{~cm}^{2}
\end{aligned}
$$

which gives: $\quad \mathrm{R}=\left(\mathrm{C}_{\mathrm{S}}-\mathrm{C}_{\mathrm{B}}\right) * 0.20$

The cumulative release $\left(\mathrm{R}_{\mathrm{C}}\right)$ over the test period is expressed as $\mu \mathrm{g} \mathrm{Cu}$ $\mathrm{cm}^{-2}$ and calculated as

$$
\mathrm{R}_{0,122}=\Sigma \mathrm{R}_{\mathrm{i}, \mathrm{j}}(\mathrm{j}-\mathrm{i})=\Sigma\left(\mathrm{R}_{\mathrm{i}}+\mathrm{R}_{\mathrm{j}}\right) / 2 *(\mathrm{j}-\mathrm{i})
$$


where:

$$
\begin{aligned}
\mathrm{R}_{0,122}= & \text { the cumulative release }\left(\mu \mathrm{g} \mathrm{Cu} \mathrm{cm}^{-2}\right) \text { from the start of the trial } \\
& \text { through to Day 122, } \\
\mathrm{R}_{\mathrm{i}, \mathrm{j}} \quad & \text { the mean release rate }\left(\mu \mathrm{g} \mathrm{Cu} \mathrm{cm}{ }^{-2} \mathrm{~d}^{-1}\right) \text { between consecutive } \\
& \text { sampling days } \mathrm{i} \text { and } \mathrm{j} \text { for all data points between the start of } \\
& \text { the trial and Day 122, } \\
\mathrm{i} \text { and } \mathrm{j} \quad & \text { time elapsed (d, days) since start of the trial for each pair of } \\
& \text { consecutive data points, specifically } 0 \text { and } 1,1 \text { and } 3,3 \text { and } 7 \\
& \text { days, etc., respectively, and } \\
= & \text { the mean release rates ( } \left.\mu \mathrm{g} \mathrm{Cu} \mathrm{cm}^{-2} \mathrm{~d}^{-1}\right) \text { for each set of triplicate } \\
& \text { test cylinders for each pair of consecutive days from the start } \\
& \text { of the trial through to Day } 122, \text { specifically Days } 0 \text { and } 1, \\
& \text { Days } 1 \text { and } 3 \text {, Days } 3 \text { and } 7, \text { etc., respectively. }
\end{aligned}
$$

The blank (= control $\mathrm{X})$ was with one exception below the detection limit, and therefore $\mathrm{C}_{\mathrm{B}}$ has been set as zero in the equation. 



\section{Results and Discussion}

\subsection{Application of paints.}

Some brush marks occurred in the resulting paint surface, as can be seen in the pictures of the painted cylinders before start and after test period, respectively, in Appendix C. When this type of paint is applied with brush it is not possible to get a completely even surface, and to some extent there will be marks from the brush depending on the properties of the paint, primarily its viscosity. However, previous experience from a ring test of the ISO copper release test method performed earlier (1997) shows that such unevenness of the surface does not significantly affect the test results.

\subsection{Holding tank and test medium.}

The $\mathrm{pH}$ of the seawater was kept at $\mathrm{pH} 8.0 \pm 0.1$ during the test. The copper concentration in the holding tank was kept below $100 \mu \mathrm{g} \mathrm{L}^{-1}$ throughout the test; see Table 2 (Appendix A). The copper concentration in the test medium before release measurement was overall very low (below the detection limit of $2-5 \mu \mathrm{g} \mathrm{L}^{-1}$ ).

\subsection{Copper release.}

All raw data from copper analyses of water from release measurements of the different tested paints is included in Appendix B together with copies of the original test protocols from the analysis laboratory (MeAna consult). The analysis results are presented in Table 6 (Appendix B), with the uncertainty of the analysis indicated as coefficient of variation $(\mathrm{CV}, \%)$, i.e. the relative standard deviation. Values below the detection limit are presented as half the detection limit value, a practice that may be used when a value must be used in calculations despite being below detection (Asante-Duah 1998).

The results are presented as release rates expressed as $\mu \mathrm{g} \mathrm{Cu} \mathrm{cm}{ }^{-2}$ day $^{-1}$, in Table 4 (Appendix A) and as graphs in Figure 1. The three different paints show very different release rate patterns. All three show low release rates day zero but whilst Fabi and Hard Racing Xtra increase rapidly Mille Xtra remains at very low release rates throughout the test. The copper concentrations obtained in the Mille Xtra measuring beakers were low throughout the test, and sometimes at or below the de- 
tection limit. Therefore, the release values fluctuate more and are more uncertain for this paint. Hard Racing Xtra increases to the highest release rate during day 21 and after that slowly decreases during the rest of test period. Fabi increases very rapidly to the highest release rate during day 1 , and decreases after that and from day 66 it is comparable to the low release rate from Mille Xtra.

The cumulative release of $\mathrm{Cu} \mathrm{cm}^{-2}$ over the entire study period of 122 days is presented in Table 5 and as graphs in Figure 2.

The copper release from the "traditional" paint (Fabi) corresponds well with what could be expected from earlier data (International 1991), both regarding the level and the pattern of release. For the two "modern" paints Mille Xtra and Hard Racing Xtra, it is more difficult to relate to earlier data. New information was submitted in 2006 (Hempel 2006), i.e. after the planning of the present study, with release data that differed from that originally submitted in 2003 (Hempel 2002a, b). The increasing release rate with time which was obvious in the tests submitted in 2003 and also could be expected to continue after the actual test duration of 45 days was no longer present in the release studies submitted in 2006. The test duration of these more recent studies was 85 days, i.e. considerably longer than the normal 45 days, and furthermore this data corresponds quite well with the results obtained in the present study. It should also be mentioned that the actual average release rates were slightly different in the two submissions: for Mille Xtra $6 \mu \mathrm{g} / \mathrm{cm}^{2} / \mathrm{d}$ (2006) as compared to 2 $\mu \mathrm{g} / \mathrm{cm}^{2} / \mathrm{d}(2003)$ and for Hard Racing Xtra $10 \mu \mathrm{g} / \mathrm{cm}^{2} / \mathrm{d}$ (2006) as compared to $12 \mu \mathrm{g} / \mathrm{cm}^{2} / \mathrm{d}$ (2003). The reasons for the observed differences are not clear, and one possibility is that the two paints have been modified since their introduction on the Swedish market in 2003. This part of the discussion which involves data previously submitted to KemI has been added to the report by KemI and the documents referred to (Hempel 2002a, b, 2006, International 1991) have not been disclosed to third party.

\subsection{Conclusion.}

It is concluded that the prolongation of a release test to 122 days may give additional information as compared to a standard 45 days test, primarily regarding how the steady-state release of a paint is reached. For the traditional type paint Fabi and the new type paint Hard Racing Xtra the release curves decrease and/or flatten out from 45 days and onwards, which could not easily be predicted from a 45 days test. For Mille Xtra a prolongation gives less additional information since the release rate is more or less constant over the entire 122 days period. 


\section{References}

Asante-Duah, K. Risk Assessment in Environmental Management - A Guide for Managing Chemical Contamination Problems. ISBN 0-47198147-8. John Wiley \& sons, 1998. ASTM. ASTM Standards. Practice for the Preparation of Substitute Ocean Water. Designation D 1141-98. ASTM International, West Conshohocken, PA, United States, 1998.

ASTM. ASTM Standards. Standard Test Method for Determination of Copper Release Rate from Antifouling Coatings in Substitute Ocean Water. Designation D 6442-05. ASTM International, West Conshohocken, PA, United States, 2005.
Hempel A/S. Leach rate determination of 71100-30390 paint containing cuprous oxide. Case Consulting Laboratories, Inc. Unpublished, 2002a.

Hempel A/S. Leach rate determination of 71420-31750 paint containing cuprous oxide. Case Consulting Laboratories, Inc. Unpublished, 2002b.

Hempel A/S. Copper release rate from Hempel's Mille Xtra (71100) and Hempel's Hard Racing Xtra (71420) for Sweden. Hempel A/S. Unpublished, 2006.

International Paint. Copper release rates for Fabi, measured by International Paint Standard Method 56B1. Unpublished, 1991. 



\section{Sammanfattning}

Syftet med denna studie var att utvärdera om det är möjligt att förlänga en standardmetod för mätning av läckage av aktiv substans, i första hand koppar, från antifoulingprodukter. Målet var att erhålla mer information om produkternas läckageprofil, som kan vara av betydelse för utvärdering av deras effekter på den akvatiska miljön. Långtidsmätning (122 dagar) av kopparläckage har studerats för tre olika fritidsbåtfärger på den svenska marknaden. Slutsatsen av studien är att en förlängd test kan ge ytterligare information jämfört med en standardtest på 45 dagar, framför allt avseende hur läckaget hos en färg stabiliseras på en nivå som består under längre tid, s.k. steady-state. 



\section{Appendices}

\section{A. Figures.}

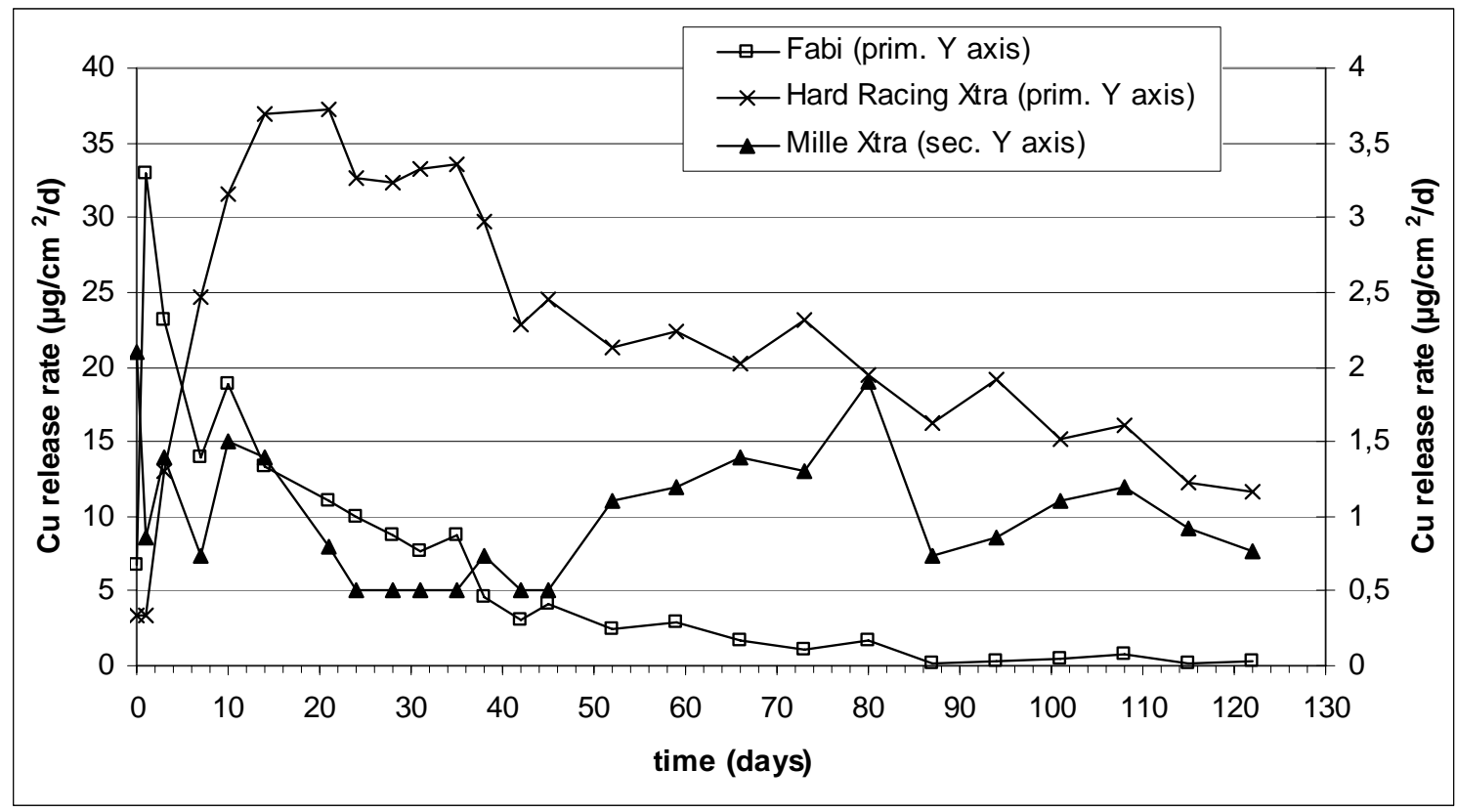

Figure 1 Release rates of $\mathrm{Cu}$ from the three studied paints over the entire test period. Data points are means of three measurements. The release rates are also listed in Table 5. Note that there are different scales on the primary (left) and secondary (right) Y axes.

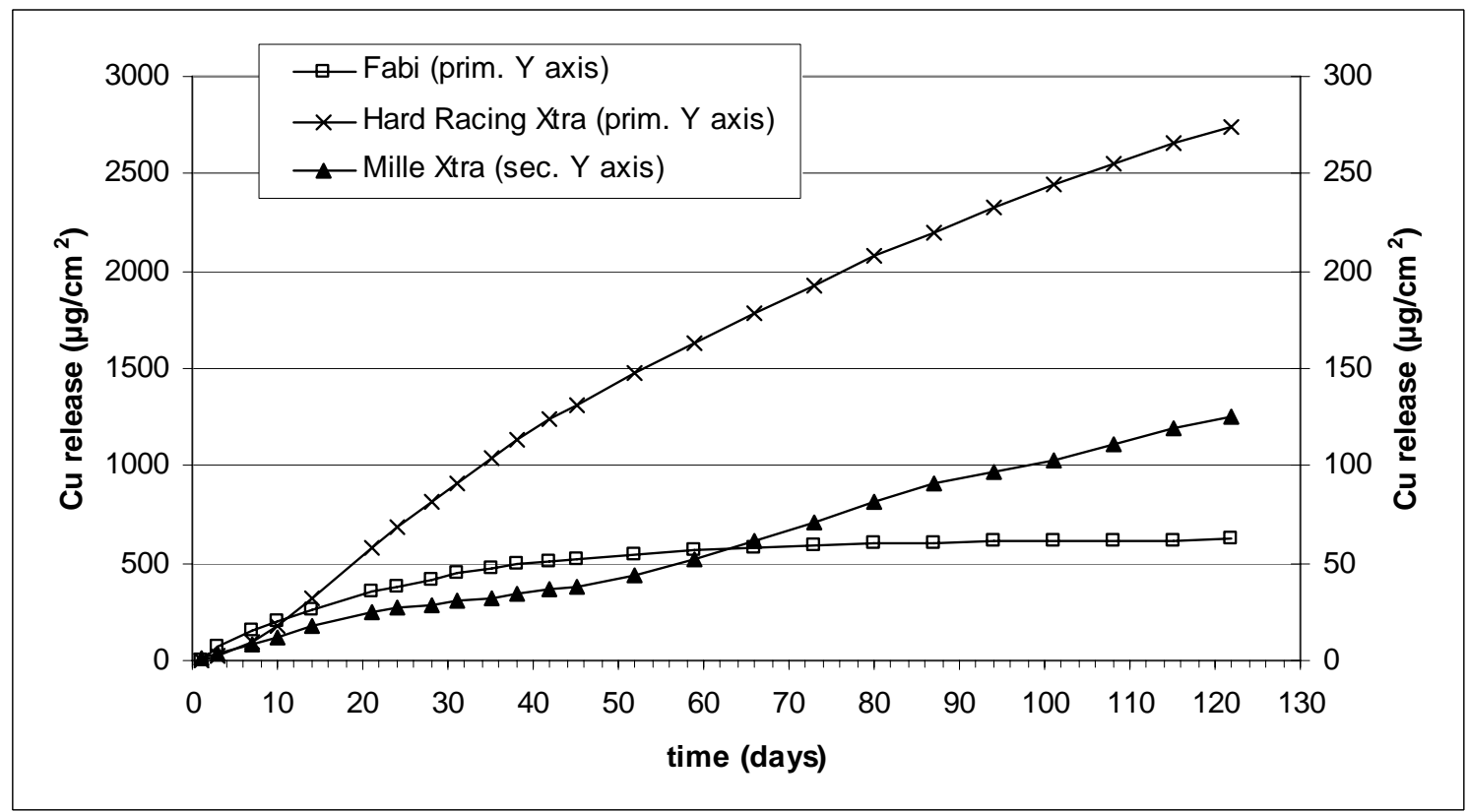

Figure 2 Cumulative release of $\mathrm{Cu}$ from the three studied paints over the entire test period. Data points are means of three measurements. The release rates are also listed in Table 6. Note that there are different scales on the primary (left) and secondary (right) $Y$ axes. 


\section{B. Tables.}

Table 2 Concentrations of $\mathrm{Cu}\left(\mu \mathrm{g} \mathrm{L}^{-1}\right)$ in the test medium before release measurement (Test Water), in water from the control cylinder after release measurement (Control X) and in the holding tank water (Holding Tank I and II); n.a. = not analysed

\begin{tabular}{|c|c|c|c|c|c|}
\hline & Day & Test Water & Control $\mathrm{X}$ & Holding Tank I & Holding Tank II \\
\hline 060801 & 0 & $<5$ & $<5$ & $<5$ & $<5$ \\
\hline 060802 & 1 & $<5$ & $<5$ & n.a. & n.a. \\
\hline 060804 & 3 & $<5$ & $<5$ & n.a. & n.a. \\
\hline 060808 & 7 & $<5$ & $<5$ & 22 & 5 \\
\hline 060811 & 10 & $<5$ & $<5$ & n.a. & n.a. \\
\hline 060815 & 14 & $<5$ & $<5$ & n.a. & n.a. \\
\hline 060822 & 21 & $<5$ & $<5$ & n.a. & n.a. \\
\hline 060825 & 24 & $<5$ & $<5$ & n.a. & n.a. \\
\hline 060829 & 28 & $<5$ & $<5$ & n.a. & n.a. \\
\hline 060901 & 31 & $<5$ & $<5$ & n.a. & n.a. \\
\hline 060905 & 35 & $<5$ & $<5$ & n.a. & n.a. \\
\hline 060908 & 38 & $<5$ & $<5$ & n.a. & n.a. \\
\hline 060912 & 42 & $<5$ & $<5$ & n.a. & n.a. \\
\hline 060915 & 45 & $<5$ & $<5$ & 19 & $<5$ \\
\hline 060922 & 52 & $<2$ & $<2$ & n.a. & n.a. \\
\hline 060929 & 59 & $<2$ & $<2$ & n.a. & n.a. \\
\hline 061006 & 66 & $<2$ & 7.0 & n.a. & n.a. \\
\hline 061013 & 73 & $<2$ & $<2$ & n.a. & n.a. \\
\hline 061020 & 80 & 8 & $<2$ & n.a. & n.a. \\
\hline 061027 & 87 & $<2$ & $<2$ & 10 & 3 \\
\hline 061103 & 94 & $<2$ & $<2$ & n.a. & n.a. \\
\hline 061110 & 101 & $<2$ & $<2$ & n.a. & n.a. \\
\hline 061117 & 108 & $<2$ & $<2$ & n.a. & n.a. \\
\hline 061124 & 115 & $<2$ & $<2$ & n.a. & n.a. \\
\hline 061201 & 122 & $<2$ & $<2$ & $<2$ & $<2$ \\
\hline
\end{tabular}


Table 3 Results from measurements of $\mathrm{pH}$, salinity and temperature in the holding tank water (Holding Tank) and test medium before release measurement (Test Water) during the study. Days of release measurement are marked with yellow background colour. $\mathbf{n m}=$ not easured

\begin{tabular}{|c|c|c|c|c|c|c|c|}
\hline \multirow[t]{2}{*}{ Date } & \multirow[t]{2}{*}{ Day } & \multicolumn{3}{|c|}{ Holding Tank } & \multicolumn{3}{|c|}{ Test Water } \\
\hline & & $\mathrm{pH}$ & Salinity & Temp & $\mathrm{pH}$ & Salinity & Temp \\
\hline 060801 & 0 & 7.99 & 33.80 & 24.10 & 8.04 & 33.40 & 25.20 \\
\hline 060802 & 1 & 8.04 & 34.00 & 24.30 & 8.02 & 33.50 & 25.10 \\
\hline 060804 & 3 & 8.05 & 33.60 & 24.40 & 8.04 & 33.90 & 25.60 \\
\hline 060806 & 5 & 8.07 & 33.90 & 24.10 & 8.13 & 34.60 & 25.30 \\
\hline 060808 & 7 & 8.08 & 33.60 & 24.10 & 8.11 & 33.30 & 25.10 \\
\hline 060811 & 10 & 8.05 & 33.30 & 24.20 & 8.13 & 33.90 & 25.30 \\
\hline 060815 & 14 & 8.07 & 33.60 & 23.60 & 8.14 & 33.40 & 24.50 \\
\hline 060816 & 15 & 8.05 & 33.20 & 24.80 & 8.10 & 33.70 & 25.60 \\
\hline 060818 & 17 & 8.06 & 33.40 & 24.70 & 8.09 & 33.20 & 25.40 \\
\hline 060820 & 19 & 8.07 & 33.70 & 24.70 & 8.09 & 33.30 & 25.50 \\
\hline 050826 & 20 & 8.09 & 34.00 & 24.10 & 8.11 & 33.30 & 24.80 \\
\hline 060822 & 21 & 8.06 & 33.60 & 24.20 & 8.08 & 33.40 & 24.80 \\
\hline 060825 & 24 & 8.05 & 33.40 & 24.10 & 8.08 & 33.20 & 24.80 \\
\hline 060827 & 26 & 8.07 & 33.70 & 24.30 & 8.09 & 33.30 & 24.90 \\
\hline 060829 & 28 & 8.06 & 33.60 & 24.10 & 8.08 & 33.60 & 24.80 \\
\hline 060901 & 31 & 8.09 & 34.10 & 24.00 & 8.09 & 33.90 & 24.80 \\
\hline 060902 & 32 & 8.02 & 33.20 & 24.10 & 8.02 & 34.10 & 24.90 \\
\hline 060905 & 35 & 7.98 & 34.00 & 26.10 & 7.95 & 33.0 & 28.10 \\
\hline 060908 & 38 & 8.04 & 33.90 & 23.90 & 7.98 & 33.70 & 25.60 \\
\hline 060910 & 40 & 8.05 & 33.30 & 26.00 & 7.95 & 34.00 & 28.20 \\
\hline 060912 & 42 & 8.08 & 34.10 & 24.90 & 8.00 & 33.60 & 26.50 \\
\hline 060913 & 43 & 8.00 & 33.20 & 26.60 & 8.02 & 33.60 & 28.70 \\
\hline 060915 & 45 & 8.05 & 33.70 & 24.40 & 8.08 & 33.80 & 25.60 \\
\hline 060917 & 47 & 8.03 & 33.70 & 24.10 & 8.08 & 33.90 & 25.10 \\
\hline 060919 & 49 & 8.04 & 33.50 & 24.30 & 8.04 & 33.30 & 25.20 \\
\hline 060922 & 52 & 8.06 & 33.30 & 24.10 & 8.05 & 33.50 & 24.90 \\
\hline 060927 & 57 & 8.05 & 34.10 & 23.70 & 8.07 & 33.80 & 24.40 \\
\hline 060929 & 59 & 8.00 & 33.70 & 24.10 & 8.01 & 33.20 & 24.90 \\
\hline 060930 & 60 & 8.02 & 33.60 & 24.00 & 8.05 & 33.40 & 25.00 \\
\hline 061001 & 61 & 8.03 & 33.80 & 24.10 & 8.05 & 33.40 & 24.90 \\
\hline 061003 & 63 & 8.05 & 33.20 & 24.00 & 8.06 & 33.70 & 24.80 \\
\hline 061006 & 66 & 8.05 & 33.40 & 24.00 & 8.07 & 33.10 & 24.80 \\
\hline 061007 & 67 & 8.04 & 33.70 & 24.10 & 8.08 & 33.30 & 24.90 \\
\hline 061009 & 69 & 8.05 & 34.10 & 23.80 & 8.02 & 33.60 & 24.80 \\
\hline 061011 & 71 & 8.01 & 33.50 & 23.90 & 8.03 & 33.40 & 24.80 \\
\hline 061013 & 73 & 8.02 & 33.90 & 23.80 & 8.04 & 33.50 & 24.80 \\
\hline 061014 & 74 & 8.03 & 33.20 & 23.80 & 8.06 & 33.80 & 24.80 \\
\hline 061017 & 77 & 8.02 & 34.00 & 23.40 & 8.01 & 33.70 & 24.50 \\
\hline 061020 & 80 & 7.99 & 33.60 & 23.80 & 8.00 & 33.70 & 24.80 \\
\hline 061022 & 82 & 8.00 & 34.10 & 24.00 & 8.04 & 33.90 & 25.00 \\
\hline 061026 & 86 & 8.03 & 33.90 & 23.80 & 8.04 & 33.60 & 24.90 \\
\hline 061027 & 87 & 8.03 & 33.20 & 23.80 & 8.04 & 33.20 & 24.90 \\
\hline 061029 & 89 & 8.03 & 33.60 & 23.40 & 8.08 & 33.60 & 24.80 \\
\hline 061101 & 92 & 8.04 & 34.00 & 23.00 & 8.07 & 33.60 & 24.50 \\
\hline 061103 & 94 & 8.02 & 33.30 & 23.60 & 8.04 & 33.50 & 24.90 \\
\hline 061105 & 96 & 8.03 & 34.00 & 23.70 & 8.07 & 33.70 & 25.00 \\
\hline 061108 & 99 & 8.03 & 33.60 & 23.70 & 8.02 & 33.70 & 24.90 \\
\hline 061110 & 101 & 8.04 & 34.10 & 23.70 & 8.02 & 33.60 & 25.10 \\
\hline 061112 & 103 & 8.04 & 33.60 & 23.70 & 8.09 & 33.90 & 24.90 \\
\hline 061114 & 105 & 8.06 & 33.20 & 23.70 & 8.05 & 33.70 & 24.90 \\
\hline 061117 & 108 & 8.01 & 33.70 & 24.00 & 8.02 & 33.60 & 25.10 \\
\hline 061119 & 110 & 8.02 & 39.60 & 24.00 & 8.03 & 39.30 & 25.20 \\
\hline 061121 & 112 & 8.01 & 37.80 & 24.00 & 8.01 & 37.40 & 25.20 \\
\hline 061123 & 114 & 8.03 & 36.20 & 23.40 & 8.03 & 35.50 & 25.20 \\
\hline 061124 & 115 & $\mathrm{~nm}$ & $\mathrm{~nm}$ & $\mathrm{~nm}$ & $\mathrm{~nm}$ & $\mathrm{~nm}$ & $\mathrm{~nm}$ \\
\hline 061125 & 116 & 8.03 & 34.60 & 23.90 & 8.03 & 33.90 & 24.90 \\
\hline 061129 & 120 & 8.02 & 35.00 & 24.00 & 8.02 & 35.60 & 25.10 \\
\hline 061201 & 122 & 8.04 & 33.50 & 23.90 & 8.02 & 33.30 & 24.90 \\
\hline
\end{tabular}


Table 4 Raw data from analyses of samples from each cylinder in release measurements presented as the concentration of copper, together with the mean value for each paint and sampling occasion $\left(\mu \mathrm{g} \mathrm{Cu} \mathrm{I}^{-1}\right)$. Values below the detection limit are presented as half the detection limit value. $\mathrm{CV}=$ Coefficient of variation. , $\#=$ MeAna sample no.

\begin{tabular}{|c|c|c|c|c|c|c|c|}
\hline & Day & \# & Fabi & \# & Mille Xtra & \# & Hard Racing Xtra \\
\hline \multirow[t]{5}{*}{20060801} & 0 & 5 & 33 & 8 & 8 & 11 & 13 \\
\hline & & 6 & 39 & 9 & 12 & 12 & 21 \\
\hline & & 7 & 28 & 10 & 11 & 13 & 15 \\
\hline & & Mean & 33.3 & Mean & 10.3 & Mean & 16.3 \\
\hline & & $\mathrm{CV}$ & 16.6 & $\mathrm{CV}$ & 20.2 & $\mathrm{CV}$ & 25.5 \\
\hline \multirow[t]{5}{*}{20060802} & 1 & 16 & 159 & 19 & 8 & 22 & 17 \\
\hline & & 17 & 157 & 20 & 2.5 & 23 & 17 \\
\hline & & 18 & 179 & 21 & 2.5 & 24 & 16 \\
\hline & & Mean & 165.0 & Mean & 4.3 & Mean & 16.7 \\
\hline & & $\mathrm{CV}$ & 7.4 & $\mathrm{CV}$ & 74.0 & $\mathrm{CV}$ & 3.5 \\
\hline \multirow[t]{5}{*}{20060804} & 3 & 27 & 135 & 30 & 10 & 33 & 66 \\
\hline & & 28 & 105 & 31 & 6 & 34 & 64 \\
\hline & & 29 & 106 & 32 & 5 & 35 & 65 \\
\hline & & Mean & 115.3 & Mean & 7.0 & Mean & 65.0 \\
\hline & & $\mathrm{CV}$ & 14.8 & $\mathrm{CV}$ & 37.9 & $\mathrm{CV}$ & 1.5 \\
\hline \multirow[t]{5}{*}{20060808} & 7 & 40 & 67 & 43 & 6 & 46 & 100 \\
\hline & & 41 & 70 & 44 & 2.5 & 47 & 147 \\
\hline & & 42 & 73 & 45 & 2.5 & 48 & 124 \\
\hline & & Mean & 70.0 & Mean & 3.7 & Mean & 123.7 \\
\hline & & $\mathrm{CV}$ & 4.3 & $\mathrm{CV}$ & 54.6 & $\mathrm{CV}$ & 19.0 \\
\hline \multirow[t]{5}{*}{20060811} & 10 & 51 & 95 & 54 & 8 & 57 & 150 \\
\hline & & 52 & 95 & 55 & 6 & 58 & 152 \\
\hline & & 53 & 92 & 56 & 8 & 59 & 170 \\
\hline & & Mean & 94.0 & Mean & 7.3 & Mean & 157.3 \\
\hline & & $\mathrm{CV}$ & 1.8 & $\mathrm{CV}$ & 15.6 & $\mathrm{CV}$ & 7.0 \\
\hline \multirow[t]{5}{*}{20060815} & 14 & 62 & 66 & 65 & 7 & 68 & 174 \\
\hline & & 63 & 66 & 66 & 11 & 69 & 196 \\
\hline & & 64 & 68 & 67 & 2.5 & 70 & 185 \\
\hline & & Mean & 66.7 & Mean & 6.8 & Mean & 185.0 \\
\hline & & $\mathrm{CV}$ & 1.7 & $\mathrm{CV}$ & 62.5 & $\mathrm{CV}$ & 6.0 \\
\hline \multirow[t]{5}{*}{20060822} & 21 & 73 & 57 & 76 & 2.5 & 79 & 186 \\
\hline & & 74 & 56 & 77 & 7 & 80 & 184 \\
\hline & & 75 & 54 & 78 & 2.5 & 81 & 190 \\
\hline & & Mean & 55.7 & Mean & 4.0 & Mean & 186.7 \\
\hline & & $\mathrm{CV}$ & 2.8 & $\mathrm{CV}$ & 65.0 & $\mathrm{CV}$ & 1.6 \\
\hline \multirow[t]{5}{*}{20060825} & 24 & 84 & 50 & 87 & 2.5 & 90 & 148 \\
\hline & & 85 & 51 & 88 & 2.5 & 91 & 175 \\
\hline & & 86 & 49 & 89 & 2.5 & 92 & 168 \\
\hline & & Mean & 50.0 & Mean & 2.5 & Mean & 163.7 \\
\hline & & $\mathrm{CV}$ & 2.0 & $\mathrm{CV}$ & 0 & $\mathrm{CV}$ & 8.6 \\
\hline \multirow[t]{5}{*}{20060829} & 28 & 95 & 43 & 98 & 2.5 & 101 & 166 \\
\hline & & 96 & 43 & 99 & 2.5 & 102 & 162 \\
\hline & & 97 & 46 & 100 & 2.5 & 103 & 158 \\
\hline & & Mean & 44.0 & Mean & 2.5 & Mean & 162.0 \\
\hline & & $\mathrm{CV}$ & 3.9 & $\mathrm{CV}$ & 0 & $\mathrm{CV}$ & 2.5 \\
\hline \multirow[t]{5}{*}{20060901} & 31 & 106 & 40 & 109 & 2.5 & 112 & 145 \\
\hline & & 107 & 38 & 110 & 2.5 & 113 & 177 \\
\hline & & 108 & 38 & 111 & 2.5 & 114 & 177 \\
\hline & & Mean & 38.7 & Mean & 2.5 & Mean & 166.3 \\
\hline & & $\mathrm{CV}$ & 3.0 & $\mathrm{CV}$ & 0 & $\mathrm{CV}$ & 11.1 \\
\hline \multirow[t]{5}{*}{20060905} & 35 & 117 & 42 & 120 & 2.5 & 123 & 170 \\
\hline & & 118 & 41 & 121 & 2.5 & 124 & 170 \\
\hline & & 119 & 44 & 122 & 2.5 & 125 & 162 \\
\hline & & Mean & 42.3 & Mean & 2.5 & Mean & 167.3 \\
\hline & & $\mathrm{CV}$ & 3.6 & $\mathrm{CV}$ & 0 & $\mathrm{CV}$ & 2.8 \\
\hline \multirow{5}{*}{20060908} & 38 & 128 & 21 & 131 & 6 & 134 & 162 \\
\hline & 38 & 129 & 23 & 132 & 2.5 & 135 & 154 \\
\hline & & 130 & 25 & 133 & 2.5 & 136 & 131 \\
\hline & & Mean & 23.0 & Mean & 3.7 & Mean & 149.0 \\
\hline & & $\mathrm{CV}$ & 8.7 & $\mathrm{CV}$ & 54.6 & CV & 10.8 \\
\hline
\end{tabular}


Table 4 continued.

\begin{tabular}{|c|c|c|c|c|c|c|c|}
\hline Date & Day & $\#$ & Fabi & $\#$ & Mille Xtra & $\#$ & Hard Racing Xtra \\
\hline \multirow[t]{5}{*}{20060912} & 42 & 139 & 15 & 142 & 2.5 & 145 & 118 \\
\hline & & 140 & 17 & 143 & 2.5 & 146 & 115 \\
\hline & & 141 & 14 & 144 & 2.5 & 147 & 110 \\
\hline & & Mean & 15.3 & Mean & 2.5 & Mean & 114.3 \\
\hline & & CV & 10.0 & $\mathrm{CV}$ & 0 & $\mathrm{CV}$ & 3.5 \\
\hline \multirow[t]{5}{*}{20060915} & 45 & 152 & 22 & 155 & 2.5 & 158 & 126 \\
\hline & & 153 & 19 & 156 & 2.5 & 159 & 126 \\
\hline & & 154 & 20 & 157 & 2.5 & 160 & 116 \\
\hline & & Mean & 20.3 & Mean & 2.5 & Mean & 122.7 \\
\hline & & $\mathrm{CV}$ & 7.5 & $\mathrm{CV}$ & 0 & CV & 4.7 \\
\hline \multirow[t]{5}{*}{20060922} & 52 & 163 & 11 & 166 & 5.5 & 169 & 110 \\
\hline & & 164 & 13 & 167 & 6.7 & 170 & 109 \\
\hline & & 165 & 14 & 168 & 5 & 171 & 100 \\
\hline & & Mean & 12.7 & Mean & 5.7 & Mean & 106.3 \\
\hline & & $\mathrm{CV}$ & 12.1 & $\mathrm{CV}$ & 15.3 & $\mathrm{CV}$ & 5.2 \\
\hline \multirow[t]{5}{*}{20060929} & 59 & 174 & 14 & 177 & 6.4 & 180 & 121 \\
\hline & & 175 & 14 & 178 & 5.5 & 181 & 110 \\
\hline & & 176 & 15 & 179 & 6 & 182 & 105 \\
\hline & & Mean & 14.3 & Mean & 6.0 & Mean & 112.0 \\
\hline & & CV & 4.1 & $\mathrm{CV}$ & 7.5 & CV & 7.3 \\
\hline \multirow[t]{5}{*}{20061006} & 66 & 185 & 6.2 & 188 & 11 & 191 & 99 \\
\hline & & 186 & 6.7 & 189 & 6 & 192 & 102 \\
\hline & & 187 & 12 & 190 & 4.6 & 193 & 102 \\
\hline & & Mean & 8.3 & Mean & 7.2 & Mean & 101.0 \\
\hline & & CV & 38.7 & $C V$ & 46.7 & $\mathrm{CV}$ & 1.7 \\
\hline \multirow[t]{5}{*}{20061013} & 73 & 196 & 5 & 199 & 7 & 202 & 113 \\
\hline & & 197 & 6 & 200 & 7 & 203 & 120 \\
\hline & & 198 & 6 & 201 & 5 & 204 & 113 \\
\hline & & Mean & 5.7 & Mean & 6.3 & Mean & 115.3 \\
\hline & & $\mathrm{CV}$ & 10.2 & $\mathrm{CV}$ & 18.3 & $\mathrm{CV}$ & 3.5 \\
\hline \multirow{5}{*}{20061020} & 80 & 207 & 13 & 210 & 8 & 213 & 97 \\
\hline & & 208 & 7 & 211 & 10 & 214 & 100 \\
\hline & & 209 & 5 & 212 & 11 & 215 & 94 \\
\hline & & Mean & 8.3 & Mean & 9.7 & Mean & 97.0 \\
\hline & & CV & 50.0 & $\mathrm{CV}$ & 16.0 & CV & 3.0 \\
\hline \multirow[t]{5}{*}{20061027} & 87 & 220 & 1 & 223 & 3 & 226 & 83 \\
\hline & & 221 & 1 & 224 & 5 & 227 & 78 \\
\hline & & 222 & 1 & 225 & 3 & 228 & 82 \\
\hline & & Mean & 1.0 & Mean & 3.7 & Mean & 81.0 \\
\hline & & $\mathrm{CV}$ & 0 & $\mathrm{CV}$ & 31.0 & $\mathrm{CV}$ & 3.0 \\
\hline \multirow[t]{5}{*}{20061103} & 94 & 231 & 2 & 234 & 4.7 & 237 & 112 \\
\hline & & 232 & 1 & 235 & 3.9 & 238 & 88 \\
\hline & & 233 & 2.8 & 236 & 4.3 & 239 & 87 \\
\hline & & Mean & 1.9 & Mean & 4.3 & Mean & 95.7 \\
\hline & & $\mathrm{CV}$ & 47.0 & $\mathrm{CV}$ & 9.0 & $\mathrm{CV}$ & 15.0 \\
\hline \multirow[t]{5}{*}{20061110} & 101 & 242 & 2 & 245 & 4.9 & 248 & 75 \\
\hline & & 243 & 1 & 246 & 5.8 & 249 & 77 \\
\hline & & 244 & 3.2 & 247 & 5.7 & 250 & 76 \\
\hline & & Mean & 2.1 & Mean & 5.5 & Mean & 76.0 \\
\hline & & $\mathrm{CV}$ & 52.4 & $\mathrm{CV}$ & 8.9 & $\mathrm{CV}$ & 1.3 \\
\hline \multirow[t]{5}{*}{20061117} & 108 & 253 & 4.1 & 256 & 6.9 & 259 & 88 \\
\hline & & 254 & 3.9 & 257 & 5.9 & 260 & 77 \\
\hline & & 255 & 4.4 & 258 & 5.5 & 261 & 76 \\
\hline & & Mean & 4.1 & Mean & 6.1 & Mean & 80.3 \\
\hline & & CV & 6.1 & $\mathrm{CV}$ & 10.8 & CV & 8.3 \\
\hline \multirow[t]{5}{*}{20061124} & 115 & 264 & 1 & 267 & 5.5 & 270 & 69 \\
\hline & & 265 & 1 & 268 & 4.2 & 271 & 62 \\
\hline & & 266 & 1 & 269 & 4.1 & 272 & 54 \\
\hline & & Mean & 1 & Mean & 4.6 & Mean & 61.7 \\
\hline & & $\mathrm{CV}$ & 0 & $\mathrm{CV}$ & 17.0 & $\mathrm{CV}$ & 12.2 \\
\hline 20061201 & 122 & 277 & 1 & 280 & 3.7 & 283 & 49 \\
\hline 20061201 & 122 & 278 & 3 & 281 & 3.8 & 284 & 75 \\
\hline & & 279 & 1 & 282 & 3.8 & 285 & 51 \\
\hline & & Mean & 1.7 & Mean & 3.8 & Mean & 58.3 \\
\hline & & $\mathrm{CV}$ & 67.7 & $\mathrm{CV}$ & 1.6 & $\mathrm{CV}$ & 24.8 \\
\hline
\end{tabular}


Table 5 Copper release rates for the three tested paints at the respective release measurement occasions (means of three measurements, $\mu \mathrm{g} \mathrm{Cu} \mathrm{cm}^{-2} \mathrm{day}^{-1}$ ).

\begin{tabular}{|c|c|c|c|}
\hline Day & Fabi & Mille Xtra & Hard Racing Xtra \\
\hline 0 & 6.7 & 2.1 & 3.3 \\
\hline 1 & 33 & 0.9 & 3.3 \\
\hline 3 & 23.1 & 1.4 & 13 \\
\hline 7 & 14 & 0.74 & 24.7 \\
\hline 10 & 18.8 & 1.5 & 31.5 \\
\hline 14 & 13.3 & 1.4 & 37.0 \\
\hline 21 & 11.1 & 0.8 & 37.3 \\
\hline 24 & 10 & 0.5 & 32.7 \\
\hline 28 & 8.8 & 0.5 & 32.4 \\
\hline 31 & 7.7 & 0.5 & 33.3 \\
\hline 35 & 8.8 & 0.5 & 33.5 \\
\hline 38 & 4.6 & 0.74 & 29.8 \\
\hline 42 & 3.1 & 0.5 & 22.9 \\
\hline 45 & 4.1 & 0.5 & 24.5 \\
\hline 52 & 2.5 & 1.1 & 21.3 \\
\hline 59 & 2.9 & 1.2 & 22.4 \\
\hline 66 & 1.7 & 1.4 & 20.2 \\
\hline 73 & 1.1 & 1.3 & 23.1 \\
\hline 80 & 1.7 & 1.9 & 19.4 \\
\hline 87 & 0.2 & 0.74 & 16.2 \\
\hline 94 & 0.38 & 0.86 & 19.1 \\
\hline 101 & 0.42 & 1.1 & 15.2 \\
\hline 108 & 0.8 & 1.2 & 16.1 \\
\hline 115 & 0.2 & 0.92 & 12.3 \\
\hline 122 & 0.34 & 0.76 & 11.7 \\
\hline
\end{tabular}


Table 6.Cumulative copper release for the three tested paints (means of three measurements, $\mu \mathrm{g} \mathrm{Cu} \mathrm{cm}^{-2}$ ).

\begin{tabular}{lrrr}
\hline Day & Fabi & Mille Xtra & Hard Racing Xtra \\
\hline 1 & 19.9 & 1.5 & 3.3 \\
3 & 76 & 3.8 & 19.6 \\
7 & 150 & 8.0 & 95 \\
10 & 199 & 11.4 & 179 \\
14 & 264 & 17,2 & 316 \\
21 & 349 & 24,9 & 576 \\
24 & 381 & 26,8 & 681 \\
28 & 418 & 28,8 & 812 \\
31 & 443 & 30,3 & 910 \\
35 & 476 & 32,3 & 1044 \\
38 & 496 & 34,2 & 1139 \\
42 & 511 & 36,7 & 1244 \\
45 & 522 & 38,2 & 1315 \\
52 & 545 & 43,8 & 1475 \\
59 & 564 & 51.8 & 1628 \\
66 & 580 & 60.9 & 1778 \\
73 & 590 & 70.4 & 1929 \\
80 & 600 & 81.6 & 2078 \\
87 & 607 & 90,8 & 2202 \\
94 & 609 & 96.4 & 2376 \\
101 & 611 & 103 & 2446 \\
108 & 616 & 111 & 2556 \\
115 & 619 & 119 & 2655 \\
122 & 621 & 125 & 2739 \\
\hline & & &
\end{tabular}


C. Analysis protocols (6 pages).

\section{MeAna - Konsult MILJŌANALYSER}

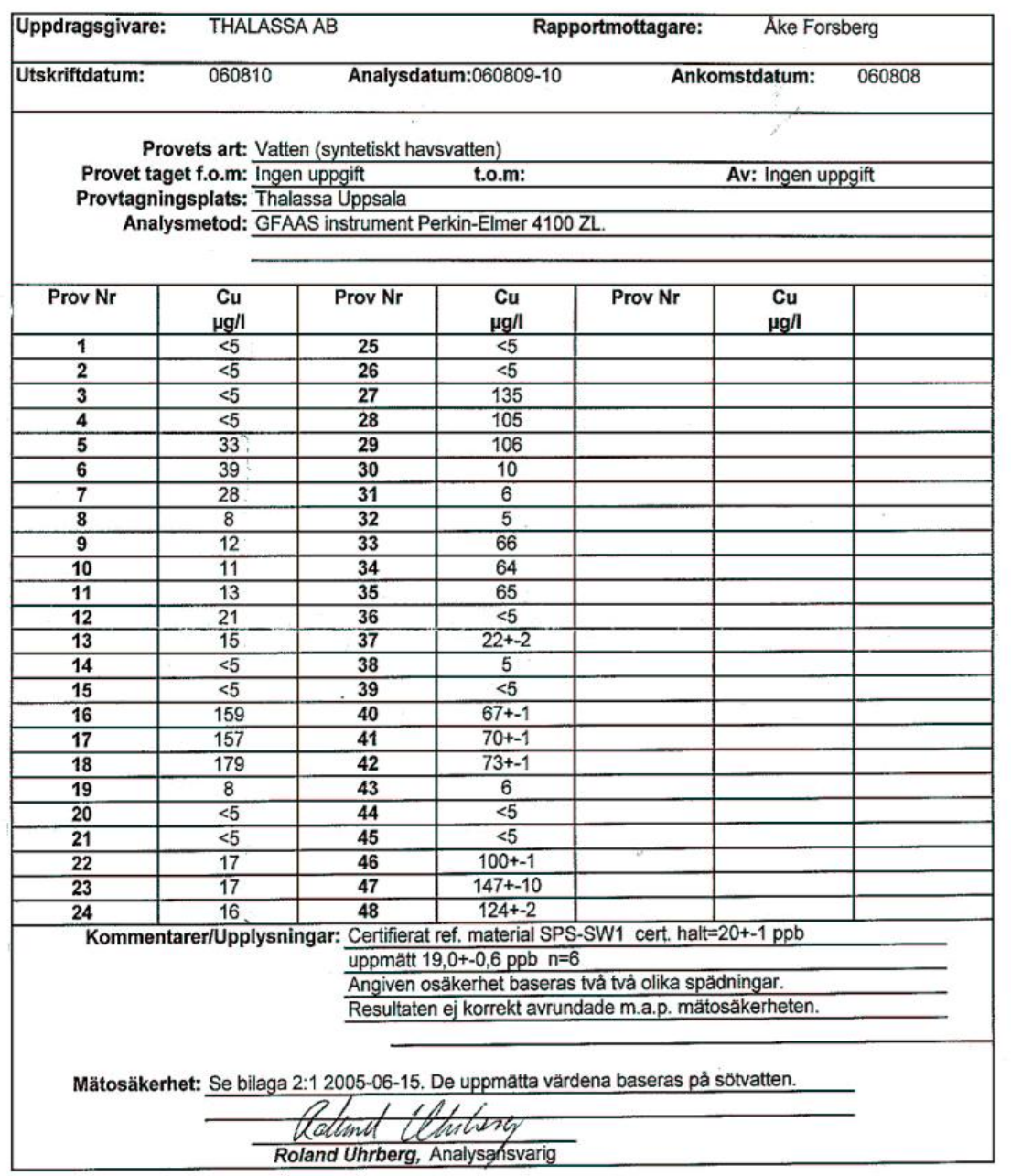

Denna rapport får endast återges i sin helhet, om inte utfärdande laboratorium $\mathrm{i}$ förväg skriftligen godkănt annat."

EKEBYVÄGEN 10 A7 75275 UPPSALA - SWEDEN TEL 018-50 6060 FAX 018-50 6065 e-mail Uhrberg@telia.com www.meana.se 


\section{MeAna - Konsult} MILJÖANALYSER

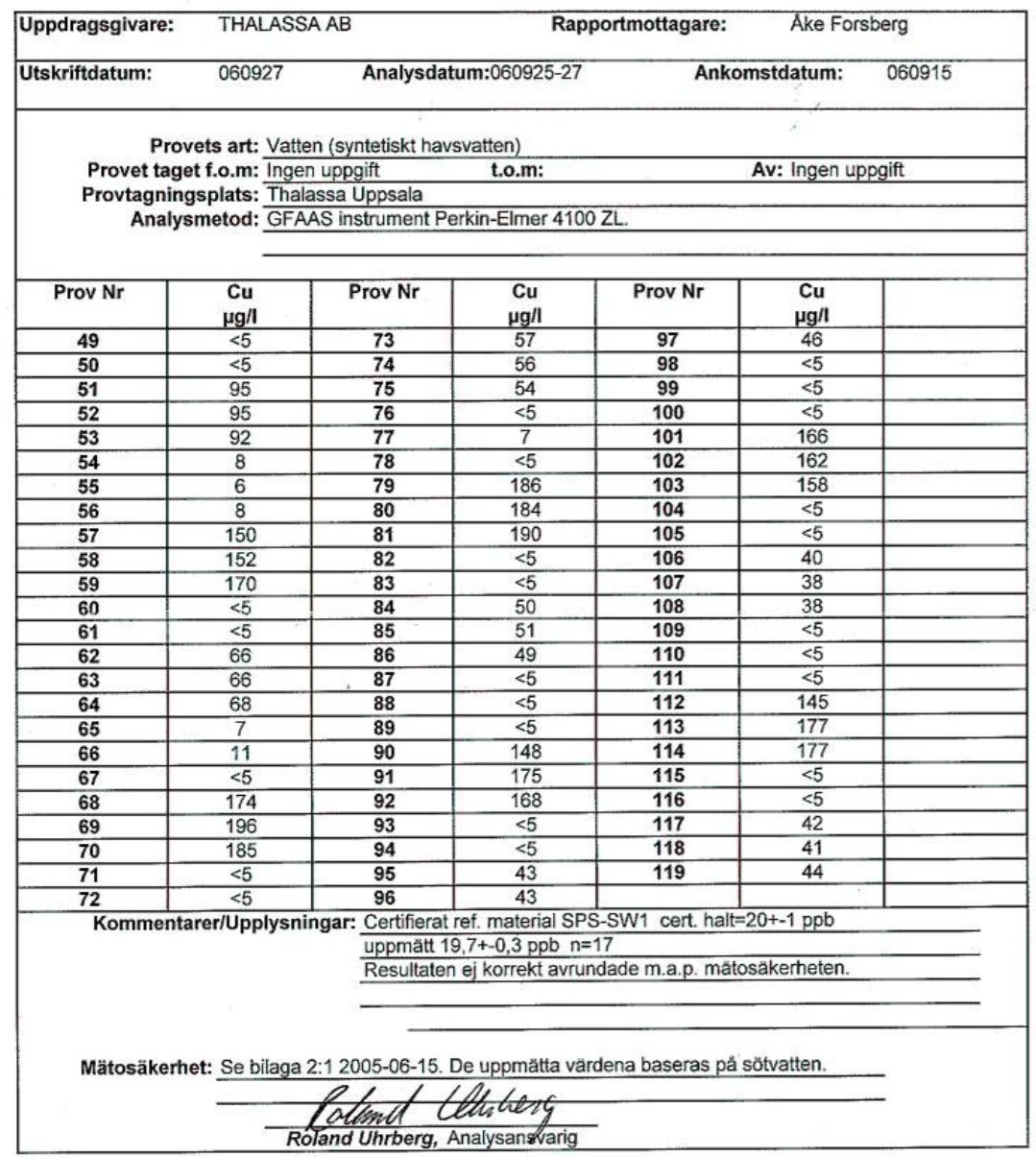

Denna rapport får endast återges i sin helhet, om inte utfärdande laboratorium i förväg skriftligen godkänt annat." 


\section{MeAna - Konsult}

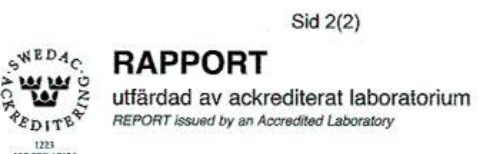
MILJOANALYSER

utfärdad av ackrediterat laboratorium

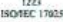

\begin{tabular}{lllcl}
\hline Uppdragsgivare: & THALASSA AB & \multicolumn{2}{c}{ Rapportmottagare: } & \multicolumn{2}{c}{ Áke Forsberg } \\
& \multicolumn{2}{l}{ Analysdatum:060925-27 } & Ankomstdatum: & 060915
\end{tabular}

Provets art: Vatten (syntetiskt havsvatten)

Provet taget f.o.m: Ingen uppgift t.o.m

Provtagningsplats: Thalassa Uppsala

t.o.m: Av: Ingen uppgift

Analysmetod: GFAAS instrument Perkin-Elmer $4100 \mathrm{ZL}$.

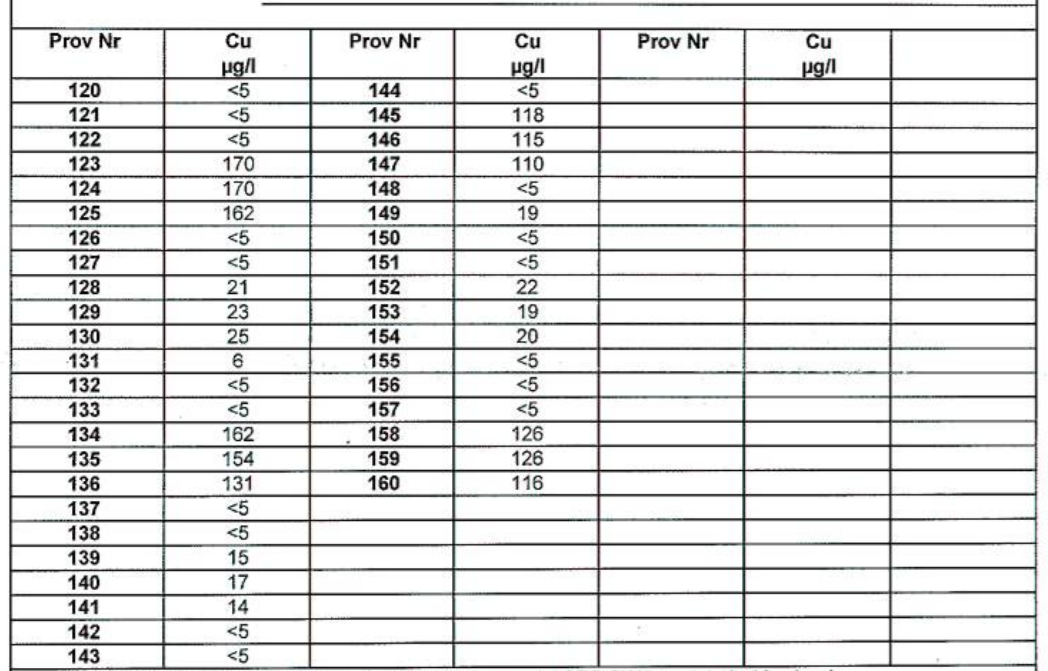

Kommentarer/Upplysningar: Certifierat ref. material SPS-SW1 cert. halt $=20+-1 \mathrm{ppb}$

uppmätt 19,7+-0,3 ppb $n=17$

Resultaten ej korrekt avrundade m.a.p. mătosäkerheten.

Mätosäkerhet: Se bilaga 2:1 2005-06-15. De uppmätta vărdena baseras pâ sơtvatten. 


\section{MeAna - Konsult} MILJOANALYSER

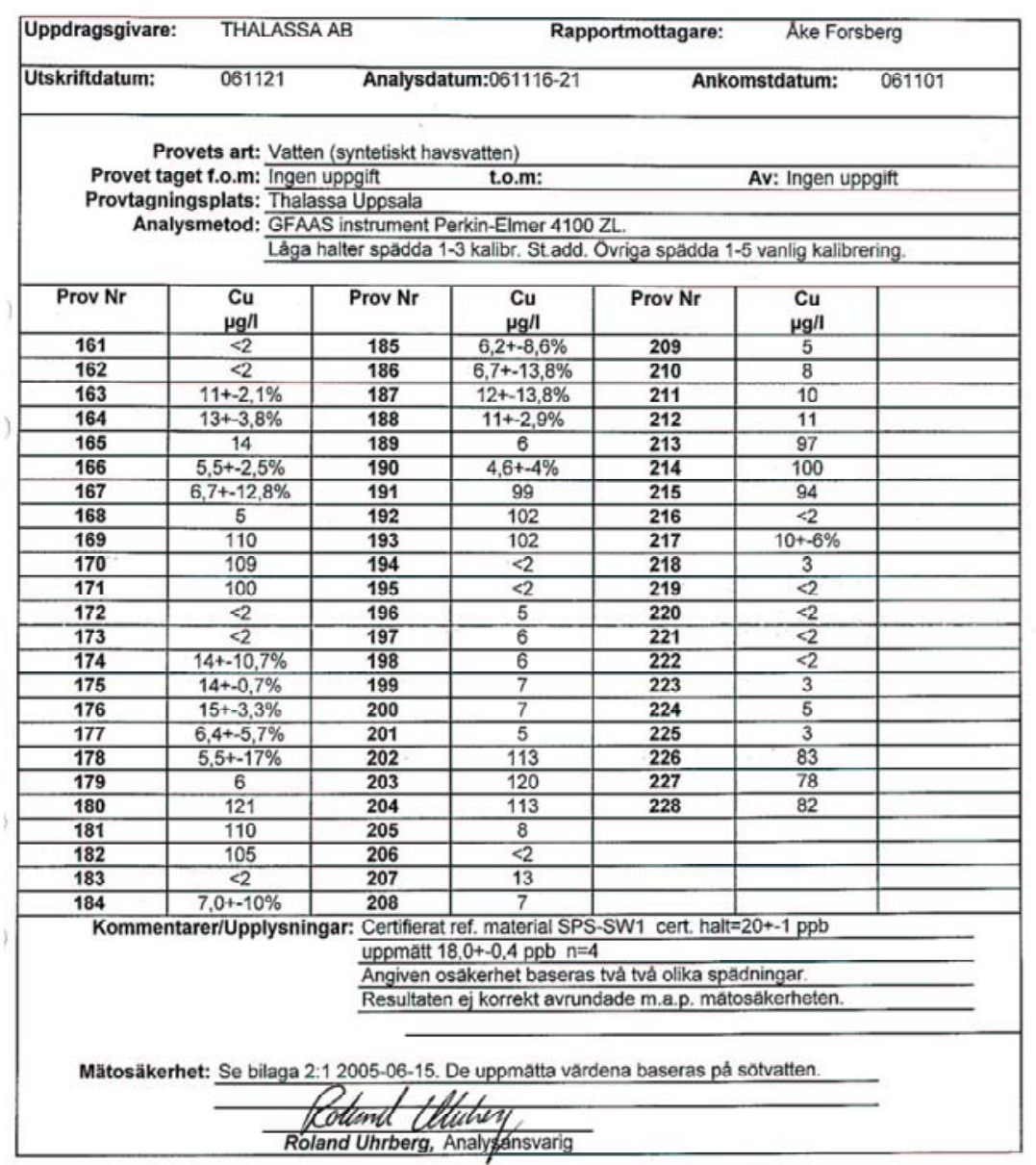

Denna rapport far endast atterges i sin helhet, om inte utfairdande laboratorium i forvăg skriftligen godkänt annat."

EKEBYVÅGEN 10 A7 75275 UPPSALA - SWEOEN TEL. 018-50 6060 FAX 018-50 6065 e-mail Uhrberg@itelia com www.meana.se 


\section{MeAna - Konsult}

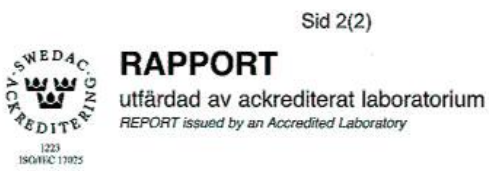

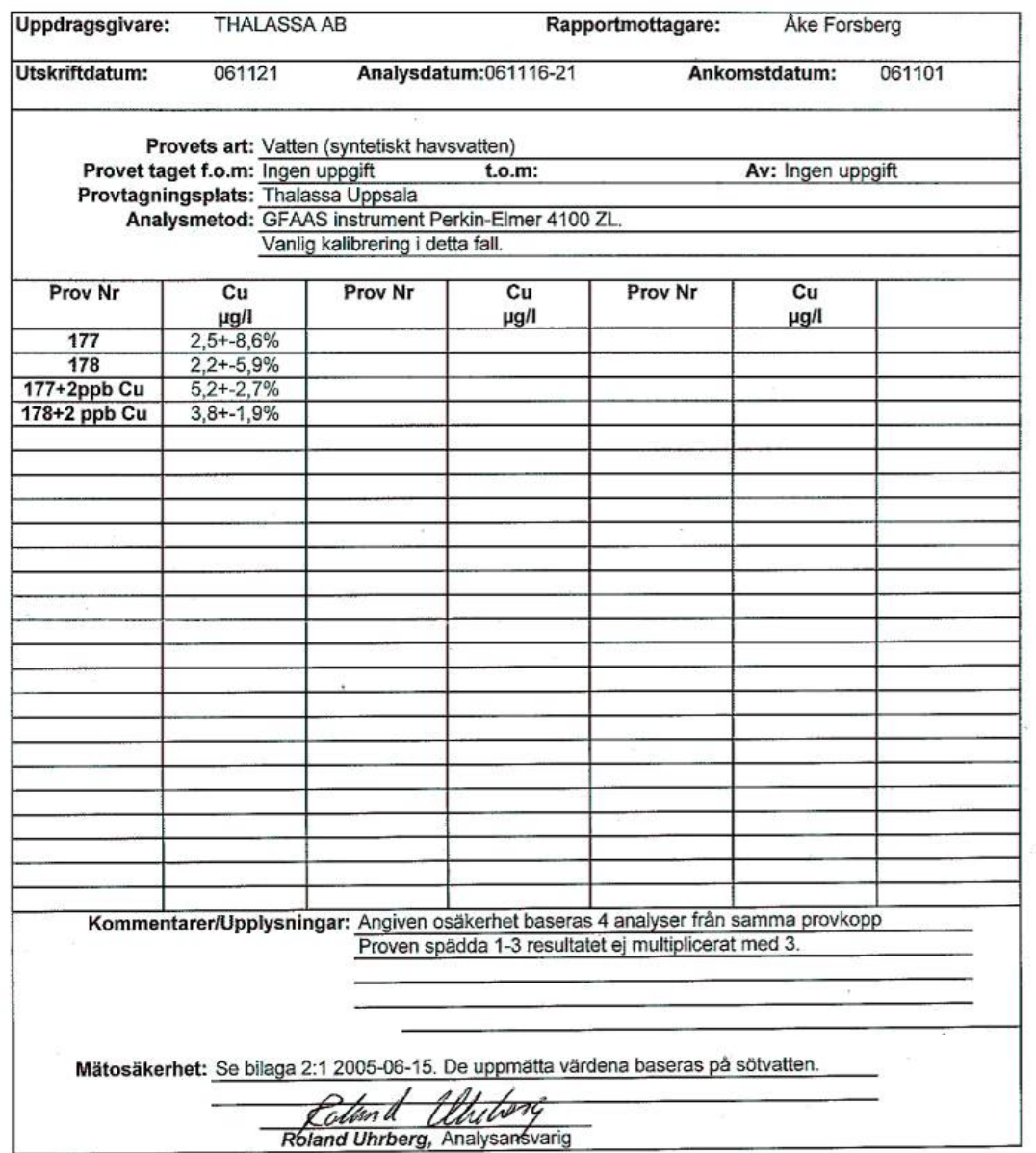

Denna rapport får endast återges i sin helhet, om inte utfärdande laboratorium i förväg skriftligen godkänt annat."

EKEBYVĀGEN 10 A7 75275 UPPSALA - SWEDEN TEL 018-50 6060 FAX 018-506065 e-mail Uhrberg@telia.com www.meana.se 


\section{MeAna - Konsult} MILJOANALYSER

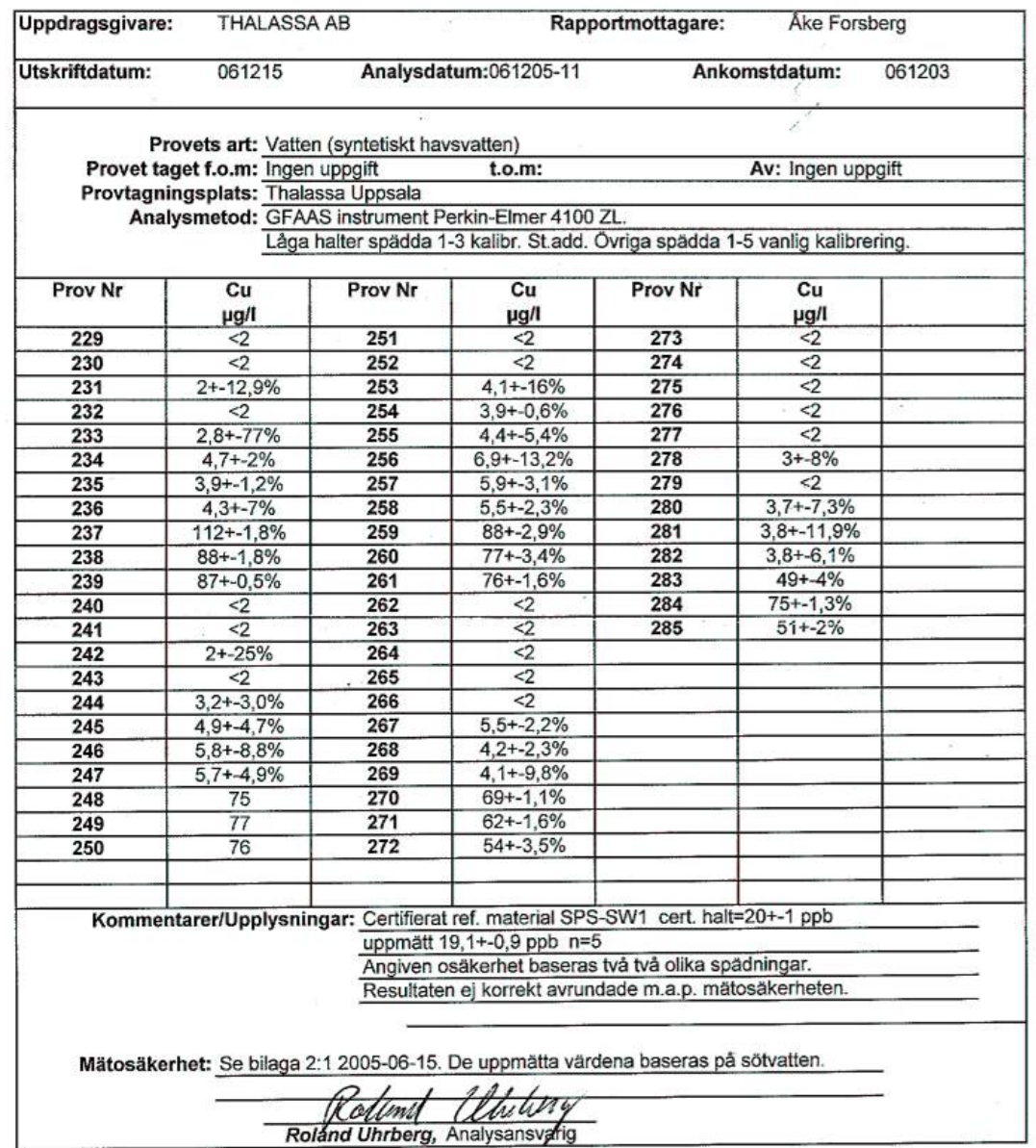

Denna rapport får endast återges i sin helhet, om inte utfarrdande laboratorium i förvăg skriftligen godkänt annat." EKEBYVÄGEN 10 A7 752 75 UPPSALA - SWEDEN TEL 018-50 6060 FAX 018-50 6065 e-mail Uhrberg@telia.com www.meana.se 
D. Photographs of test cylinders (before and after testing).
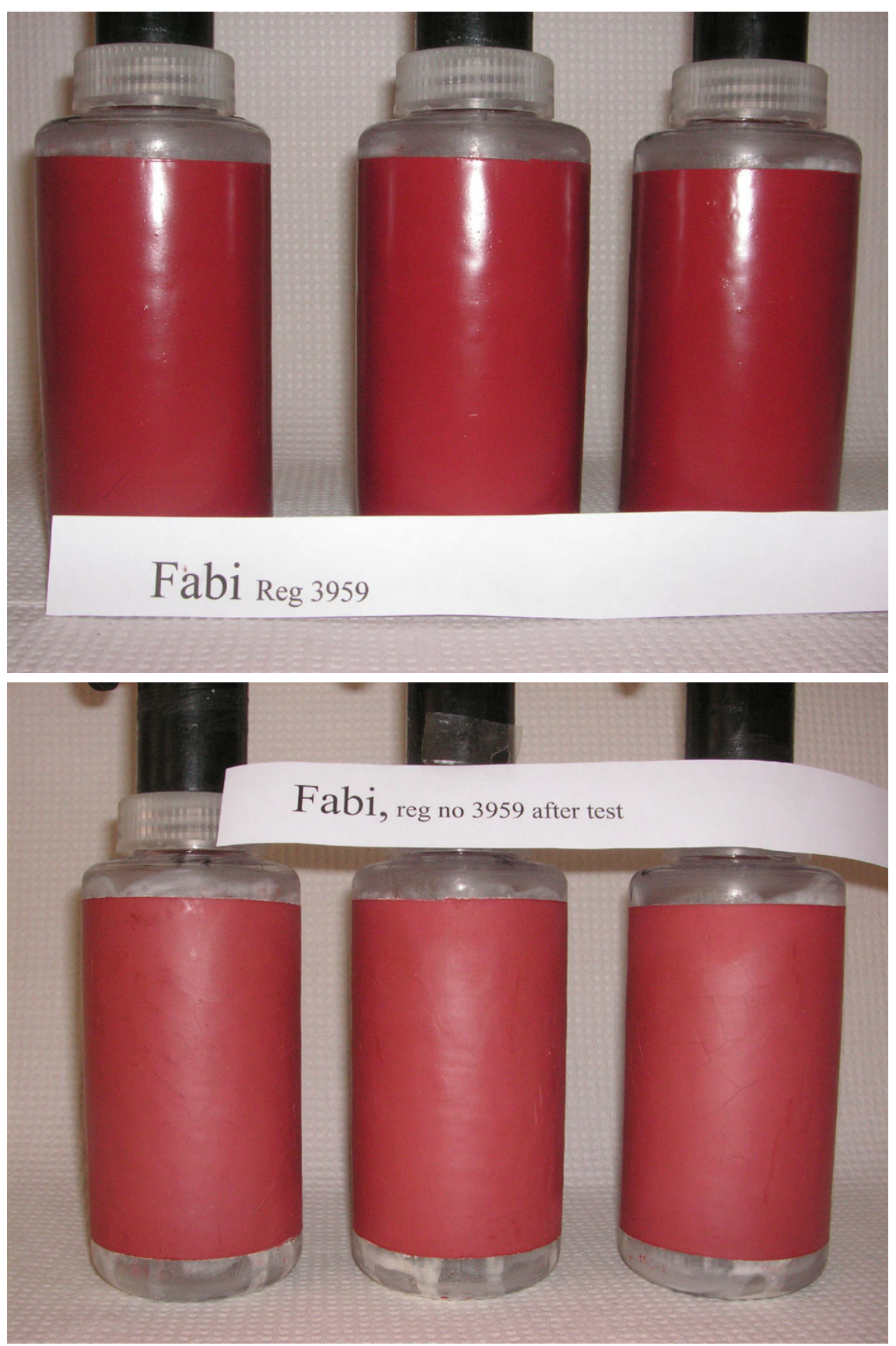

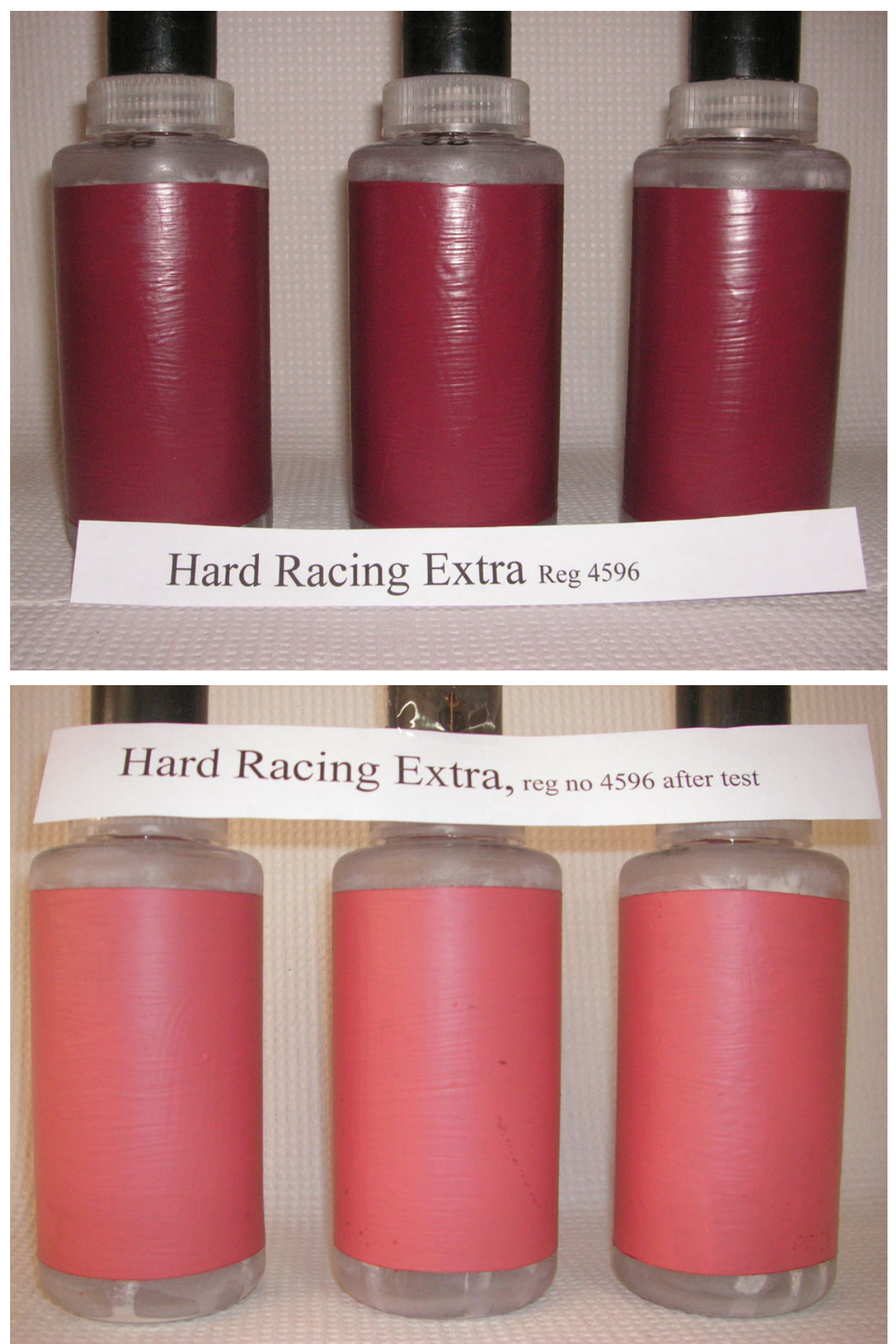

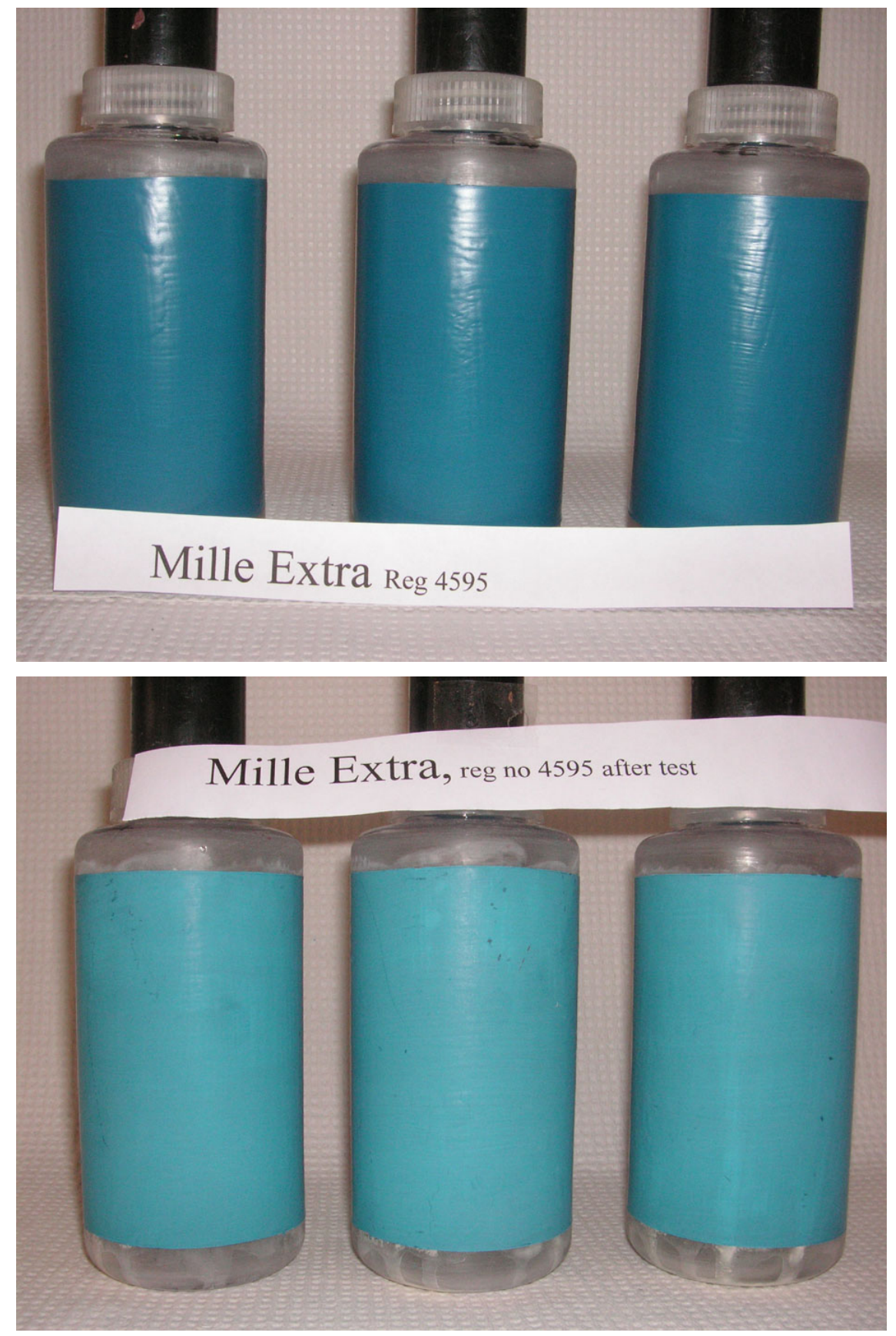